\title{
AGNIESZKA KANIA
}

Uniwersytet Zielonogórski

DOI: $10.19195 / 0137-1134.105 .4$

\section{THE DIRECTIVE FOR GENERAL PREVENTION IN EMPIRICAL APPROACH. AUTHOR'S RESEARCH*}

\section{GENERAL NOTES}

In the analysis of judicial assessment of penal sanctions we need to take into account its empirical aspect. It seems that the wide-spectrum approach towards it widens the scope of research and also allows to verify the rationalisation of proposed criminal law solutions in this subject matter.

The empirical diagnosis of judicial assessment of penal sanctions is strongly rooted in both tradition and the scope of penal thought interest present in Wrocław. It is worth noticing that this subject was already referred to in the work by B. Wróblewski and W. Świda ${ }^{1}$ before World War II. A novel approach proposed by that research and its results was found highly valuable. The work was considered innovative as it rejected classic jurisprudence notions and associated the analysis of social background of legal norms and the practical aspect of functioning of normative regulations with metalegal understanding instead ${ }^{2}$.

Judicial assessment of penal sanctions was also referred to by T. Kaczmarek. His questionnaire-based research in this field focused on factual aspect of judicial assessment of penal sanctions and examined to what extent such assessment influences the common perception ${ }^{3}$.

* This article is the result of the research conducted with the assistance of the Ministry of Science and Higher Education's grant for the research activity developing young researchers in 2013 — project no 1334/M/KPKM/13; project supervisor Agnieszka Kania.

${ }^{1}$ Cf. B. Wróblewski, W. Świda, Sędziowski wymiar kary w Rzeczypospolitej Polskiej. Ankieta, Wilno 1939, p. 1 f.

2 Cf. T. Kaczmarek, Sędziowski wymiar kary w Polskiej Rzeczypospolitej Ludowej w świetle badań ankietowych, Wrocław 1972, pp. 9-11.

3 Cf. Ibid.; compare also with further research of this author - T. Kaczmarek et al., Decyzja sędziego w sprawie wymiaru kary i jej psychospoleczne uwarunkowania, ed. T. Kaczmarek, Wrocław 1987; compare also T. Kaczmarek, J. Giezek, Decyzja sądowa w sprawie wymiaru kary 
The empirical approach towards judicial assessment of penal sanctions was also the subject of analyses by Z. Sienkiewicz. However, in her detailed research on the theoretical and practical aspects of the directive for the social peril of an act - Article $50 \S 1$ of the 1969 Polish Criminal Code (known today as the social noxiousness of an act) she didn't use previously employed questionnaire technique $^{4}$. The scope of the above analyses included a wide-spectrum research of one of the directives for judicial assessment of penal sanctions and implied the use of the so-called intense empirical method involving questionnaire interview, which as such allowed a thorough examination of respondent's personality ${ }^{5}$.

Continuing with the empirical direction in the contemplation on judicial assessment of penal sanctions, the aim of this paper, based on the questionnaire data, is to present how judges adjudicating in criminal cases in the highest instance Polish courts construe the directive for general prevention ("potrzeby w zakresie kształtowania świadomości prawnej społeczeństwa" — art. $53 \S 1$ in fine k.k.). It was the belief in the unquestioned authority of the Criminal Chamber of Supreme Court and Courts of Appeal in rendering the rulings which has determined the scope of this analysis. Their decisions are persuasive authority for lower instance adjudication $^{6}$.

\section{QUESTIONNAIRE AS AN EMPIRICAL RESEARCH METHOD}

Sociological literature underlines that the choice of research method should be natural and feature logic-driven consequence of theoretical background of a given subject matter ${ }^{7}$. In accordance with this rule, I have assumed that a questionnaire is the appropriate method for the research on the rationalisation of general prevention. It typically allows the exploration of opinions, attitudes, aspirations and views of possibly large number of respondents ${ }^{8}$. I used this widespread method for

jako przedmiot badań empirycznych. (Propozycja metodologiczna), “Państwo i Prawo” 1, 1988, pp. 29-37.

${ }^{4}$ Cf. Z. Sienkiewicz, Spoleczne niebezpieczeństwo czynu jako dyrektywa sądowego wymiaru kary (na tle teorii i praktyki sadowej), Wrocław 1977, p. 99 f.

5 Cf. W. Świda, Metody badań kryminologicznych, [in:] Kryminologia, ed. W. Świda, Warszawa 1977, p. 83.

${ }^{6}$ Cf. A. Kania, Prewencja ogólna jako dyrektywa sądowego wymiaru kary. Rozważania na tle kodeksu karnego, Wrocław 2016, s. 225-241. The choice of the said representative sample (and the method) enabled the author to avoid potential accusations of artificial group selection; since, according to W. Świda: "The questionnaire [...] usually takes into account more individuals so it is unlikely to capture given phenomenon in its whole complexity". Cf. W. Świda, op. cit., p. 81.

7 Cf. M. Malikowski, M. Niezgoda, Badania empiryczne w socjologii, Tyczyn 1997, p. 305.

8 Cf. L.A. Gruszczyński, Kwestionariusze w socjologii. Budowa narzędzi do badań surveyowych, Katowice 1999, p. 10 and L.A. Gruszczyński, Elementy metod i technik badań socjologicznych, Tychy 2002, pp. 42-43. 
the collection of empirical data - the interviewer questionnaire - and I referred to a carefully chosen representative ${ }^{9}$ group which enabled me to obtain the desired research material.

The research was conducted with the use of a written questionnaire sent to respondents by the post ${ }^{10}$. Completed questionnaires, without my interference and supervision, were subsequently sent to the facility supervising the research (University of Wrocław, Faculty of Law, Administration and Economics). The chosen method of communication was indirect, because the researcher and the respondents have never met each other in person ${ }^{11}$. Due to the choice of such method, i.e. the method of impersonal nature, it was possible to avoid individual contacts between the researcher and the respondents. It also prevented the occurrence of potential problems connected with interpersonal relationships. The common view that may be found in the sociological literature is that the interviewed individuals tend to feel a decreased anonymity, unlike the individuals who complete questionnaires ${ }^{12}$. Subconscious fear of being identified can become even so strong that

9 Cf. W. Świda, op. cit., p. 74.

${ }^{10}$ We can enlist several questionnaire types basing on the criterion of its distribution and returning to the researcher: 1) mail questionnaire, distributed and sent back by post, 2) press questionnaire, published in the press and sent back by post, 3) questionnaire attached to consumer goods sent back by post, 4) TV, radio and telephone questionnaire, distributed through mass communication and returned by post, 5) hand out questionnaire, involving personal engagement of the researcher in the distribution and collection, 6) auditory questionnaire, made among formally dependent individuals, e.g. at school or in the army; distribution of questions and collection of answers under researcher's supervision, 7) public questionnaire, publicly available and with a specified place of return. There are also questionnaire types categorised by the form of its distribution: written, audio or visual. On the other hand, we can also enumerate questionnaires basing on the method of communication between the researcher and respondents. They may be self-returnable (when they do not require personal engagement of the researcher) or made under his/her supervision (the involvement of researcher is necessary particularly when it comes to the explanation of questions to respondents). Moreover, many sociological works pay close attention to possible segregation of questions according to the subject matter of the research or to the researcher him/herself. Cf. J. Lutyński, "Wywiad kwestionariuszowy a ankieta", [in:] Wywiad kwestionariuszowy. Analizy teoretyczne i badania empiryczne, ed. K. Lutyńska, A.P. Wejland, Wrocław 1983, p. 55-57; J. Wódz, Socjologia dla prawników i politologów, Warszawa 2000, pp. 164; A. Pieniążek, M. Stefaniuk, Socjologia prawa. Zarys wykładu, Kraków 2001, p. 146.

11 Considering the criterion of communication between researcher and respondents (in the process of empirical data collection) we can enlist methods involving direct communication (free interview techniques, questionnaire interview techniques) and indirect communication (techniques for obtaining non-standardised written statements and survey techniques). Cf. J. Lutyński, "Ankieta i jej rodzaje na tle podziału technik otrzymywania materiałów", [in:] Analizy i próby technik badawczych w socjologii. t. 2, ed. Z. Gostkowski, J. Lutyński, Wrocław 1968, p. 29.

12 However, the use of questionnaire implies certain doubts as to the methodology. W. Świda sees several disadvantages in this technique: the risk of insufficient representativeness, incorrect form of questionnaire, wrong layout of questions and asking sensitive questions. He also mentions that questionnaire gives only an approximate result because it is impossible to avoid all mistakes. He believes that the interpretation of answers presents real difficulty, especially, when respondents 
it eventually may prevent the respondents from giving answers in line with their actual beliefs ${ }^{13}$. The above mentioned expressive relationship distortions usually manifest themselves in two ways, either in purposeful refusal to speak (even if they have something to say); or in giving an answer contradictory to respondents' true beliefs ${ }^{14}$. What is more, the questionnaire technique was also chosen due to the character of the interview which inherently involves the influence of the researcher on final answers ${ }^{15}$.

The prepared questionnaire had a coherent structure and was handed to respondents in such form ${ }^{16}$. A comprehensive formulation of questions was meant to encourage unconstrained answers of the researched group. The questionnaire consisted of the following types of questions: maximally open-ended ${ }^{17}$, semi open-ended (involving a justification for given answers) ${ }^{18}$ and categorised (polytomous) questions where respondents have more than two answers ${ }^{19}$. In order to

fail to refer to all questions. Nonetheless he concludes: "still, it is better to learn about a given phenomenon from the questionnaire than basing on the subjective knowledge. Considering the above, it is vital to say that the questionnaire allows us to collect the desired empirical data in a relatively short time". Cf. W. Świda, Kryminologia, Warszawa 1977, pp. 80-81; B. Hołyst, Kryminologia, Warszawa 1994, p. 104.

13 Cf. J. Lutyński, "Wywiad kwestionariuszowy a ankieta”, [in:] Wywiad..., p. 58.

14 Cf. S. Nowak, Metodologia badań socjologicznych, Warszawa 1970, p. 117.

15 Cf. J. Krak, "Style przeprowadzania wywiadu i konsekwencje ich zastosowania", [in:] Wywiad kwestionariuszowy. Analizy teoretyczne i badania empiryczne, ed. K. Lutyńska, A.P. Wejland, Wrocław 1983, p. 421; compare also Z. Gostkowski, O zatożeniach i potrzebie empirycznych badań nad technikami i procedurami badawczymi w socjologii, [in:] Analizy i próby technik badawczych w socjologii. t. 1, ed. Z. Gostkowski, Wrocław 1966, p. 21. It seems obvious that the said interview, being a specific type of social interaction, implies per se that the researched: [...] would not remain neutral but they would react in a certain way to researcher's contact and tools he/she uses. They would become involved revealing potential expectations, doubts, etc. influenced by the fact they are in the centre of interest". Idem, O zatożeniach..., p. 19.

16 Cf. L.A. Gruszczyński, Kwestionariusze w socjologii. Budowa narzędzi do badań..., pp. 90-91. It has to be noted that the respondents are lawyers and their answers are not burdened with error of presumption of expertise.

17 Cf. W. Świda, op. cit., p. 75. Maximally open-ended questions, in his view, give respondent a chance to share his/her remarks.

18 Sociological literature admits that both open-ended and close-ended questions have their advantages and disadvantages. First of all, it is underlined that open-ended questions do not require respondent to be synthetic, they are more flexible and they also minimise the risk of random answers. At the same time, there is a considerable difficulty in categorising them in particular when they come in many different versions. On the other hand, it is safe to assume that close-ended questions categorisation do not present much difficulties. Nonetheless, it is also mentioned that this type of questions limits respondents' freedom of expressing their opinions, especially when possible answers do not correlate with their views. Cf. A. Pieniążek, M. Stefaniuk, op. cit., pp. 147-148; compare also J.J. Shaughnessy, E.B. Zechmeister, J.S. Zechmeister, Metody badawcze w psychologii, trans. M. Rucińska, Gdańsk 2002, p. 485.

${ }^{19}$ According to W. Swida categorised questions are not perfect solution as well. They tend to be suggestive, however, they offer a deeper insight into the subject matter and it is easier for the 
avoid a straightforward suggestion of the answer in this type of question, a psychometric scale of multiple-choice responses instead of single-choice responses was proposed. The cone like order of questions enabled us to initially ask about general issues and to subsequently proceed to more detailed ones ${ }^{20}$.

The questionnaire was divided into three main parts. The first one included strictly informative questions enabling gathering basic data about respondents like professional experience and the history of adjudicating in criminal cases. The second part consisted of 10 meritorious questions, mostly requiring the respondent to express his or her attitude towards the present wording of the directive for the general prevention. The last part concerned respondents' opinions and proposals de lege ferenda, in addition to statements expressed in previous questions.

In accordance with formal instructions for conducting such survey, the questionnaire was introduced by a letter encouraging respondents to give possibly exhaustive answers. This cover letter referred to the importance of survey's subject matter in the light of judicial practise and emphasised the role of exceptional expertise and professional experience of the judges adjudicating in highest instance courts in Poland. What is more, in order to limit any possible prejudices and constraints while giving answers, the respondents were assured that the research is conducted by a reliable university - level institution, and it will remain fully anonymous.

Attempting to evaluate the reasons for choosing the questionnaire technique for this research one should note that despite certain criticism present in the literature questioning or even challenging its value, the aforementioned method is surely a recognised and valuable tool. Information gathered during the research allows us to confront the doctrinal understanding of the role and function of the directive for general prevention with its strictly practical understanding ${ }^{21}$. Thus, potential allegations claiming that the empirical research based on simple techniques is not precise enough - according to T. Kaczmarek - can be compared to a grievance against scuba diver who does not dive in the Pacific Ocean (not having the proper equipment), but dives in the shallow sea without required safety measures reporting his own expedition ${ }^{22}$. So we might as well assume that the allegations against the results of the research on the judicial assessment of penal sanctions are made by some authors because they have insufficient research experience and a naive presumption that there are some complex vehicles allowing the examination of the factual but not externalised mechanisms governing this

researcher to subsequently segregate the answers. Cf. W. Świda, op. cit., p. 76; T. Kaczmarek, Sędziowski wymiar kary..., p. 16.

20 W. Świda, op. cit., s. 78.

${ }^{21}$ Cf. T. Kaczmarek, "W odpowiedzi na recenzję Andrzeja Zolla”, Nowe Prawo 1977, pp. 10 11, p. 113.

22 Cf. A. Podgórecki, Prestiż prawa, Warszawa 1966, p. 161. 
process $^{23}$. Notwithstanding, the empirical value of the research conducted in this field, one must conclude that the knowledge based on it is more credible than the random intuitive knowledge ${ }^{24}$.

\section{QUESTIONNAIRE RESEARCH RESULTS}

The prepared questionnaires were sent to the Supreme Court's Criminal Chamber as well as to Criminal Departments of all Courts of Appeal in Poland (altogether 11 courts). The completed questionnaires were returned (from May to August 2012) by: the Supreme Court's Criminal Chamber and the Criminal Departments of all Courts of Appeal in the following cities: Wrocław, Poznań, Rzeszów, Warszawa, Lublin, Katowice and Łódź. After an initial verification, it was determined that the questionnaires were correctly filled in, so it was possible to examine judges' construal of the Criminal Code directive for general prevention. The completed by respondents 45 questionnaires allowed both for the quantitative and qualitative overview of the gathered material.

The first question of the questionnaire read: What aim(s) do you take into account while sentencing the offender (please mark one or more answers)? The purpose of this question was to find out what motivates judges' decisions while passing a sentence. Possible answers to this categorised question were not limited so the respondents had an opportunity to answer it not only in relation to present legislation. We have proposed the following options: a) the objective to sentence an offender in accordance with the extent of his/her guilt and with the social noxiousness of an act; b) the deterrent for other potential offenders discouraging them from turning to crime; c) moral and educational influence on the society; d) preventive and educational influence on the sentenced person; e) other aims - please specify. All judges answered this question. After a further analysis it was noted that: 7 judges indicated only one aim of the sanction expressing the unanimous belief that its objective should match the extent of offender's guilt and the social noxiousness of an act. Interestingly enough only one judge did not find it important. After a closer examination of the given answers it was concluded that: 6 judges marked every objective suggested in the answers. Answers a (objective of the justice), c (objective of the positive prevention), $d$ (objective of the specific prevention) were chosen by 15 judges. Answers a (objective of the justice) and c (objective of the positive prevention) were chosen by 4 judges. Answers a (objective of the justice) and d (objective of the specific prevention) were chosen by 12 judges. Only three judges

${ }^{23}$ Cf. T. Kaczmarek, "Uwagi o badaniach empirycznych w prawie karnym”, Acta Universitatis Wratislaviensis, Państwo i Prawo CXXV, 1985, p. 37; compare also A. Zoll, Recenzja pracy T. Kaczmarka, “Ogólne dyrektywy sądowego wymiaru kary w teorii i praktyce sądowej”, „Państwo i Prawo" 7, 1981, p. 112.

${ }^{24}$ Cf. T. Kaczmarek, Sędziowski wymiar kary..., p. 14. 
attempted to specify other aims (answer e) referring to: 1) the pursuit of justice motivation, 2) the behaviour and motivation of an offender, factors determining his/ her personality and 3) victim's belief that his/her legal interest is protected.

The above question constituted the introduction into the questionnaire's subject matter. It was supposed to determine whether judge's rationalisation of sentencing has either monistic or pluralistic character (as it distinguishes the genetic factors of crime and criminality $)^{25}$. The results allowed to conclude that the judicial assessment of penal sanctions as a whole has a multiple-rationalisation structure consisting of many different and often contradictory elements. The answers revealed that the judges also take into consideration the options which are not included in the present legislation. Interestingly enough 6 judges referred to the controversial negative prevention postulate (deterring offenders from turning to crime) which is currently not included in the Criminal Code.

The second question explored the judicial construal of the directive for general prevention contained in the Criminal Code. Possible answers included: a) informing the society of criminal law regulations currently in force; b) discouraging potential offenders from committing crimes; c) reinforcing society's trust in the law; d) moral and educational influence on the society; e) other effects - please specify. The collected data revealed that: 8 judges marked all answers, 9 judges marked answer a (informing the society about criminal law regulations currently in force) and c (reinforcing society's trust in the law), 4 judges chose answer a (informing the society of criminal law regulations currently in force), c (reinforcing society's trust in the law) and d (moral and educational influence on the society), 2 judges decided to mark answer b (discouraging the potential offenders from committing crimes), c (reinforcing society's trust in the law) and d (moral and educational influence on the society), 3 judges marked a (informing the society of criminal law regulations currently in force) and $\mathrm{d}$ (moral and educational influence on the society), also 3 judge chose $b$ (discouraging the potential offenders from committing crimes) and $\mathrm{d}$ (moral and educational influence on the society), 4 judges answered c (reinforcing society's trust in the law) and d (moral and educational influence on the society), one judge chose $b$ (discouraging the potential offenders from committing crimes) and c (reinforcing society's trust in the law), one judge marked a (informing the society of criminal law regulations currently in force), also one $b$ (discouraging the potential offenders from committing crimes), 2 judges marked c (reinforcing society's trust in the law), 6 judges decided to choose answer $d$ (moral and educational influence on the society), one judge chose e (other, specified as proportional sanction).

The answers proved that the construal of the aim of the sanction leans towards positive prevention referring verba legis to the need to develop a legal conscience among the society (Article $53 \S 1$ of the Criminal Code). Therefore, the respondents' opinion correlated with the intention of the authors of the Crim-

25 Cf. Kaczmarek, Sędziowski wymiar kary..., p. 100. 
inal Code that the positive prevention measures ought to be realised through: informing the society about criminal law regulations currently in force (a), reinforcing society's trust in the law (c), moral and educational influence on the society (d) remains convergent with the intention of the authors of the Criminal Code. On the other hand, previously noticed and disapproved deterring from turning to crime as a substantial element of the general prevention aim still remains present in the beliefs of practising lawyers.

The third question referred to the rationality of the formulation of the directive for general prevention - the judges were required to decide which version, either the one expressed in the Article $50 \S 1$ of the 1969 Criminal Code (aims concerning the social impact of the sanction) or the one from the Article $53 \S 1$ of current Criminal Code (the need to develop a legal conscience among the society), was more adequate and substantial. Upon the analysis of the answers, we found out that: 16 respondents held that the previous formulation of general prevention regulation was better in terms of substantial correctness, 26 respondents believed that the current form of the general prevention is more adequate, 3 respondents have chosen not to answer the question. In the negative assessment of the previous form of the directive judges pointed out at its unreasonableness because: 1) It is possible to efficiently influence both parties - the offender and the victim. Some respondents claimed that: 2) It is only a word play. Since the aim of both the directives from 1969 and the current one is to root the correct understanding of the law in the society and encourage it to act in accordance with it (...);3) It is a stylistic matter which is not particularly important in practise; 4) The today's formulation of the directive is semantically wider so it is more helpful in the adjudication process; 5) The previous version (...) gave reason for stricter punishment of some offences; 6) The understanding of both forms of the directive is similar. Negative opinions about the today's formulation of the directive argued that: 1) It was previously more appropriate for the accomplishment of the aims of sanction; 2) The need to develop a legal conscience among the society ought to be realised by all state authorities and it is a paradox to claim that the type and the degree of sanction are supposed to develop the legal conscience; their only purpose is to influence the society by showing that punishment is unavoidable; [3) Today's form is vividly artificial and has no didactic value; 4) Whereas the previous form included the deterring element which, one way or another, remains a vital part of the sanction.]

Considering the answers given it should be noted that there were no extreme statements neither fully negating nor praising the former directive for general prevention. The approval for the current form of the directive was not based on the arguments of the meritorious nature, but it was rather neutral, praising neither its normative structure nor its construal proposed by its authors.

The fourth question made an attempt to determine what elements - according to the respondents - constitute the contents of the directive for general prevention. The proposed answers included: a) knowledge and professional experience; 
b) public opinion's views on the criminal policy; c) statistics concerning the image of crime; d) other data. Two judges marked all answers. One judge chose a (knowledge and professional experience), $\mathrm{c}$ (statistics concerning the image of crime) and $\mathrm{d}$ (other data). Two judges have decided to mark a (knowledge and professional experience) and d (other data). Twelve judges chose answers a (knowledge and professional experience) and (statistics concerning the image of crime). One judge answered $b$ (public opinion's views on the criminal policy) and 27 judges marked a (knowledge and professional experience).

In respondents' opinion the most important factor in the construal of the directive for general prevention was knowledge and judge's professional experience (44 marks). In the light of the above, it was vital to determine whether such understanding of the directive actually limits the so-called judicial adjudicating discretion. Respondents believe that judges are given a certain leeway in the process of the construal of the directive. The answers revealed that the so-called judicial intuition was a decisive factor in the construal of the general prevention aim. The collected data undermined the presumption of the authors of the Criminal Code that the substance of the directive for general prevention should be determined by the level of society's satisfaction derived from criminal sanctions offenders are subjected to ${ }^{26}$.

The next question concerned a potential ability to distinguish the types of offences which are penalised basing on the general prevention rationalisation. In case of positive answers the respondents were asked to specify the direction of the general prevention and to choose between aggravation and mitigation of sanction. One judge failed to answer the question, 30 gave negative answer and 14 proposed to distinguish crime types basing on the general prevention rationalisation. The crimes aggravating the sanction (for general prevention reasons) included: offences against the Republic of Poland (it was justified by the need of identification of the society with the national interest), offences against: property (because they are recurring), against life, the administration of justice, public order, elections, the functioning of the state, public transportation safety, organised crime, hooliganism, corruption, offences committed during natural disasters, as well as drug related offences. The aforementioned opinions correlated with the judicial construal of the directive for general prevention expressed in the Criminal Code from the year 1969. Pursuant to the views of that time, held by the judiciary, the grounds for the aggravation of penalty were often found in the very directive for general prevention. Considering the differences in axiology and criminal policy between the present and the former criminal code, it seems that judges' opinions revealed in this research might seem somewhat controversial if we tried to con-

${ }^{26}$ Cf. K. Buchała, "Głos w dyskusji”, [in:] Problemy reformy prawa karnego, ed. T. Bojarski, E. Skrętowicz, Lublin 1993, pp. 339-340. 
front them with the positive prevention objectives which contradict the previous negative approach to a certain degree 27 .

In the sixth question the respondents were asked to share their view on the role of the public opinion in the process of the assessment of penal sanction. The collected data showed that: 39 respondents gave a negative answer claiming that social sentiments are not accurate enough to be taken into consideration in the adjudication process, 5 judges gave positive answers (compromise answers, in fact), one judge omitted the question. The dominant approach was expressed by the following statements: 1) "(...) I believe that the general knowledge of the judge about the scale of a given offence along with the circumstances of the case and complete information about the defendant suffices to decide about the penal sanction"; 2) "Court's decision cannot be based on the public expectation as to the "proper" punishment for the offender"; 3 ) "The court operates in certain social environment (bound by social service) and this fact has certain implications for the adjudication. I keep that in mind when I make a decision (it is my knowledge based on a daily life observation, newspapers, literature, news and other sources) but I believe that considering public opinion views is not the same thing. Besides, there is no such medium which would allow us to accurately and holistically capture the public opinion views on a certain case or even on the broader context connected with the case. By no means we are entitled to adjudicate in accordance with the views of the community engaged in the case for such opinions are usually emotional and biased"; 4) "I believe that courts' decisions should influence the public opinion and not the other way round. This is particularly important because the public's opinion in Poland is manipulated"; 5) "The public opinion is often subject to a political manipulation by the media"; 6) "We should create such needs instead of taking them into account". Furthermore, the respondents who gave the positive (compromise) answers were additionally asked to enlist the cases which require to refer to the public opinion. Only two judges did that. They claimed that it was not possible to categorise offences which required to resort to the opinion of the society, indicating in the same time the sources of information regarding public opinion views, to which judges had to refer. Thus the most common answers as to the source of such information included: the mass media, the behaviour of the parties to the trial and the audience, as well as conducted conversations.

The answers proved the opinion previously expressed in the question 4 of the survey. The referral to the public opinion in order to find out whether the sanction is satisfactory for the society does not create any valuable implication for the directive for the general prevention. What is worth noticing, is that this opinion - despite the adverse representative sample - differed from the previous findings in this field. Despite the fact that, from the juristic and formal point of view,

${ }^{27}$ We have to mention that no respondent pointed to the general prevention rationalisation as a reason for the mitigation of the penal sanction. 
the answer to the above question should have been negative, the 1970s research showed that $55.6 \%$ of respondents believed it was vital to take into account the public opinion voice in the process of the assessment of sanction $(33.4 \%$ of the respondents differed in this matter $)^{28}$.

What is more, the further analysis of the collected data revealed (the already suggested fact) that all positive answers neither expressly nor definitely opted for the recognition of the views of the society in the assessment of penal sanction. Compromise answers surely reflected respondents' moderate claims that the public opinion stance might be accepted: 1) (...) to a reasonable extent; or 2) (..) to a minimal extent while basing on personal experience. One respondent made a similar point as he pointed out that: "A judge does not live in the isolation, he/ she is a part of the society and observes the everyday life. Nonetheless, he/she cannot decide basing exclusively on the social moods and expectations. He/she has to be able to face them, especially when the defendant is innocent or his/her guilt has not been proven (Article $5 \S 2$ of The Criminal Proceedings Code)". However, according to another opinion the social: "(...) beliefs should be taken into account and referred to even if they are not shared by the judges".

The seventh question attempted to specify which factors, in judges' opinion, would enable the best possible development of the legal conscience among the society. The respondents could mark more than one answer. The following options were provided: a) a fair sanction in concreto; b) the publishing of courts' decisions; c) information about pending trials in the mass media; d) presenting oral reasoning for courts' decisions in the mass media; e) the speed of adjudication and execution of sanction; f) high crime detection rate; g) other factor(s) - please specify. The analysis of the answers showed that: a (a fair sanction in concreto) had 38 marks; $\mathrm{b}$ (the publishing of courts' decisions) had 17 marks; c (information about pending trials in the mass media) had 14 marks; d (presenting oral justifications of courts' decisions in the mass media) had 22 marks; e (the speed of adjudication and execution of sanction) had 35 marks; and f (high rate crime detection) got 24 marks in total.

The answers displayed that the appropriate vehicle for the development of the legal conscience among the society is the fair sanction in concreto as well as the speed of adjudication and execution of sanction. At the same time, the respondents did not find the information about pending trials in the mass media particularly valuable factor in this matter.

28 According to T. Kaczmarek it is possible to consider a compromise answer as a correct one. However, the overall scepticism in this matter (which actually meant the approval only of these answers which denied accepting the public opinion views) was motivated by the author's belief that: "The public opinion is an extremely whimsical phenomenon and that is why the work of the administration of justice should not uncritically comply with its views. Nonetheless, judges should follow the public opinion and selectively pick out its constructive elements" Cf. T. Kaczmarek, Sędziowski wymiar kary..., pp. 287-288. 
In the eighth question the respondents were asked to provide factors which could encourage a potential offender to resign from committing a crime. The options available included: a) fear of criminal liability; b) concerns about being deprived of social status; c) individual beliefs arising from the duty of respecting the law; d) the authority of other people and institutions; e) other factor(s) - please specify. After a thorough examination of the answers we noted that: 2 judges left the question out, 5 judges chose the answer a (fear of criminal liability), 9 judges marked a (fear of criminal liability) and c (individual beliefs arising from the duty of respecting the law), 5 judges decided to choose a (fear of criminal liability), $\mathrm{b}$ (concern about being deprived of social status) and c (individual beliefs arising from the duty of respecting the law), 4 judges picked a (fear of criminal liability) and $b$ (concern about being deprived of social status), 3 judges marked a (fear of criminal liability) and e (other factor(s) - please specify), 4 judges chose c (individual beliefs arising from the duty of respecting the law), one judge answered $\mathrm{c}$ (individual beliefs arising from the duty of respecting the law) and $\mathrm{d}$ (the authority of other people and institutions), 2 judges marked a (fear of criminal liability), c (individual beliefs arising from the duty of respecting the law) and e (other factor(s) - please specify), one judge chose answer e (other factor(s) - please specify).

It seems that the main factor motivating the decision not to commit an offence is the fear of criminal liability ( 28 marks). Another important factor for the anti-criminal attitude is individual beliefs ( 21 marks). On the other hand, the factor seen as not important in this context is the authority of other people (only 1 mark). Additional factors indicated in the answer e were often: unavoidable threat of sanction, individual traits of character, crime detection rate and the lack of the opportunity to engage in illegal practises.

To sum up the given answers, we need to say that the presupposition of the influence of the negative prevention on the decrease in crime rates still exists in judges' opinions and it enjoys a certain popularity among them. On the other hand, the above answers allowed us to assume that the respondents also see the role of the social self-engagement in the process of discovering normative regulations which eventually should influence the auto-creation of legalistic attitudes.

In the next question we asked the respondents to refer to possibly any provisions of the Criminal Code and the Code of Criminal Procedure which would, in their opinion, contradict the objective of the development of legal conscience among the society. The collected data showed that: 5 judges omitted the question, 33 judges claimed there were no such provisions, and 7 judges answered affirmatively. They often accounted for the following examples of rules having little positive prevention value: consensual elements of the trial, the extraordinary mitigation of punishment in case of persons referred to as crown witnesses in sua causa and in altera causa.

The final question concerned the respondents' opinions on the general prevention's current position in the Code. Four judges restrained from answering, 33 judg- 
es approved the present directive status of general prevention, 8 judges opted for the removal of the said directive from the Code. Positive opinions were expressed with statements such as: 1) It is an important aim of the sanction; 2) The directive obliges the court to justify the grounds for its decision, including the type and the degree of sanction, even if it is contradictory with social expectations. The obligation to clarify these elements gives the society a chance for better understanding of the court's reasoning and it may suppress the unrest of victims and their relatives; 3) (...) this directive is particularly important for the attainment of the social respect to the law and for the stabilisation of the legal order; 4) Such an assumption will remain declaratory because substantially each decision of the court creates the legal conscience of the society (the only question is - "to what extent"); 5) In my opinion, it is an additional element of the creation of penalty. It is highly unlikely to sentence an individual without making a reference to the society it exists in; 6) The directive is adequately construed when: (...) the court influences the moral and legal assessment of a given offence and the public opinion has no force to control the assessment of the sanction for certain offences; 7) Courts cannot pass their judgements detached from the society. On the other hand, only a few views opposed the presence of the directive for general prevention in the Code. They brought up the following points: 1) The aim may be achieved only through the sanction which sensibly takes into account the degree of the social noxiousness of an act (thoroughly evaluated), the extent of the guilt of the offender (also prior to a detailed and convincing assessment of all circumstances which may influence the criminal culpability) and circumstances of the act itself; 2) Social existence used to determine the consciousness... Is the sanction supposed to replace the social existence now (...)?; 3) The sanction ought to refer only to the offender. Adjudicating court should consider only the offence and its circumstances; 4) From the point of view of the sanction this circumstance is ambivalent for an individualised offender; 5) The ability of considering these needs should be left to judge's sentencing discretion. A just sanction inherently fulfils this objective.

Basing on the statements above we can assume that the approval for the present status of the general prevention is not backed with strong and substantial arguments. We may suspect that the opinion expressed in the last question is the reflection of judges' traditionalism and their attachment to the image of general prevention existing in Polish criminal codifications for over 40 years.

The last part of the said questionnaire offered the judges the possibility to express additional, individual opinions related to the survey's subject matter. Most judges decided not to present any views. Some of the respondents decided to present their general conclusions as to the procedure of judicial assessment, nonetheless, they did not propose any changes de lege ferenda or judgements de lege lata concerning precisely the directive for prevention. The following statements give some idea about the final opinions: Sentencing is a way of constituting the justice in general - a judge cannot learn how to do this basing solely on regu- 
lations, norms and reforms. Other opinion suggested that: A supposition that the average assessment of the sanction is attained by a well formulated directives is a harmless naivety of theorists. Since a century (codes from 1932, 1969, 1997) it has been determined by the average established by the court practise.

The results of this research allowed us to formulate several general conclusions. According to the presented opinions, the judicial assessment of penal sanctions is based on a multi-directive rationalisation. The answers suggest that it is vital to take into account not only the positive prevention, but also the negative prevention elements in the process of the construal of the directive for general prevention. It is worth noticing that the factors determining the contents of the general prevention directive were usually based on individual professional and everyday experience which did not correlate with the construal of the directive for the general prevention proposed in The Substantiation of the Bill of the Criminal Code. What is more, we have noticed the respondents' unwillingness towards any potential amendments to the Article $53 \S 1$ of the Criminal Code. It is safe to assume that this kind of conservative approach is probably the result of a long lasting practise of accounting for the directive for general prevention in the substantiation of the court's decision.

\section{DYREKTYWA PREWENCJI OGÓLNEJ W UJĘCIU EMPIRYCZNYM. BADANIA WŁASNE}

\section{Summary}

Niniejszy artykuł stanowi rezultat badań ankietowych, które przeprowadzono wśród sędziów-karnistów, orzekających w najwyższych instancjach krajowych (tj. w Izbie Karnej i Wojskowej Sądu Najwyższego oraz w sądach apelacyjnych). Zawarte w nim informacje przedstawiają poglądy wspomnianej grupy badawczej na temat racjonalizacji ogólnoprewencyjnej. Zaprezentowane w tym opracowaniu analizy pozwoliły na sformułowanie kilku wniosków. Na podstawie zebranego materiału ustalono, że sędziowski wymiar kary opiera się na racjonalizacji wielodyrektywalnej. Z udzielonych odpowiedzi wynikało również, że przy interpretacji dyrektywy ogólnoprewencyjnej uwzględnienia wymagają nie tylko elementy pozytywno-, ale również negatywnoprewencyjne. Warto też zaznaczyć, że jako czynniki determinujące treść wskazania ogólnoprewencyjnego ankietowani wskazali najczęściej własne doświadczenia życiowe oraz zawodowe, co niewątpliwie odbiegało od propozycji wykładni dyrektywy ogólnoprewencyjnej, wyrażonej w Uzasadnieniu do projektu kodeksu karnego z 1997 r. Ponadto w wypowiedziach respondentów dostrzeżono także wyraźne zdystansowanie wobec ewentualnych ingerencji nowelizacyjnych w treść art. 53 § 1 k.k. Jak można przypuszczać, tego rodzaju zachowawcza postawa odzwierciedlała najprawdopodobniej wieloletnią praktykę powoływania w uzasadnieniach wyroków dyrektywy prewencji ogólnej.

Powyższe informacje stanowią tym samym materiał poznawczy, pomocny przy weryfikacji dotychczasowych wyobrażeń czy obiegowych osądów, jakie sformułowano na temat dyrektywy ogólnoprewencyjnej w doktrynie oraz w orzecznictwie. 